\title{
International

\section{Undergraduate Research and Student-Staff Partnerships: Supporting the Development of Student Scholars at a Canadian Teaching and Learning Institute}

Elizabeth Marquis, McMaster University

\begin{abstract}
Undergraduate research and inquiry and student-staff partnerships in teaching and learning have much in common, although their connections are not often discussed explicitly. Partnership initiatives - particularly those that engage students in collaborating with faculty/staff on disciplinary research or the scholarship of teaching and learning - share many features with undergraduate research efforts, including the potential to help students develop as active and engaged producers and scholars. Building on these connections, this article describes a unique 'student partners program' housed within the teaching and learning institute at McMaster University (Canada) considering its role in the development of outcomes desired by scholars and practitioners of undergraduate research and student-staff partnership. This assessment can assist in further consideration of the place of partnership within undergraduate research.
\end{abstract}

Keywords: co-inquiry, student-staff partnership, students as scholars, students as producers, undergraduate research

\section{doi: $10.18833 /$ spur/1/1/2}

The body of literature focusing on student-faculty partnerships in teaching, learning, and research has grown significantly in recent years (e.g., Cook-Sather, Bovill, and Felten 2014). Partnership approaches, which typically seek to engage students and faculty or staff as active collaborators on pedagogically relevant activities, have been deployed in a range of contexts, including curriculum design, pedagogic consultancy, disciplinary research, and the scholarship of teaching and learning (SoTL; Healey, Flint, and Harrington 2014). Regardless of the context, a key tenet of partnership initiatives is the need to challenge traditional power structures and expand the space for students to work alongside faculty as scholarly co-producers of teaching, learning, and knowledge. As stated by Cook-Sather, Bovill, and Felten (2014, 6-7), partnership is "a collaborative, reciprocal process, through which all participants have the opportunity to contribute equally, although not necessarily in the same ways" to teaching and learning projects.

In many respects, this work on student-faculty partnership resonates with the burgeoning body of scholarship exploring undergraduate research and inquiry. Of course, not all partnership initiatives involve research (or undergraduates), and not all undergraduate research entails partnership with faculty or staff. Where partnership initiatives focus on engaging undergraduate students as co-inquirers in discipline-based research or SoTL, however, the potential overlap is clear. For example, discussions of students as co-inquirers within the partnership literature (e.g., Werder and Otis 2010) have much in common with work addressing students as researchers (Levy 2011) or as producers (Neary 2014), insofar as all of these framings hinge on an understanding of students as active, scholarly contributors to research and education. Similarly, some work on undergraduate research (e.g., Shanahan et al. 2015) takes up issues relevant to partnership without necessarily discussing partnership by name or endorsing that framing. Indeed, comparatively little scholarship has considered explicitly the connections between these bodies of work.

There are certainly exceptions to this trend. Little (2011), for instance, includes several chapters on undergraduate 
research within an edited volume on student-staff partnership. Healey, Flint, and Harrington (2014) make these connections even more explicit, positioning "students as partners in subject-based research and inquiry" as one of four main categories of partnership and pointing to a range of examples of undergraduate research that connect with a partnership approach. Amongst other things, they consider where partnership might occur within established models of engaging students in research and inquiry, suggesting that it is more likely to be found, for example, in the "research-tutored" and "research-based" quadrants of Healey's well-known model (Healey and Jenkins 2009), or in the "student framed" modes of inquiry-based learning set out by Levy (2011). Such examples begin to make clear important points of contact between two congruent bodies of literature that have much to offer each other.

Taking this frequently overlooked congruence as its starting point, this article describes and assesses a novel "student partners program" at McMaster University in Canada, positioning this initiative as a means of fostering and supporting outcomes aligned with those desired by practitioners of undergraduate research and inquiry. Beyond noting the potential of such an initiative to promote traditional research skills, this article argues that development of the capacity to work in partnership is itself a significant scholarly outcome that considerations of undergraduate research might explore more actively. On one hand, the ability to collaborate meaningfully with a range of research partners is itself a useful skill, particularly given the increasing prominence of collaborative research and the commonality of group work across a range of life situations. At the same time, by emphasizing deep and active engagement in education as a process (rather than consumption of it as a reified product), student-faculty partnerships can contribute to destabilizing the dominant, neoliberal metaphor of students as consumers in higher education (McCulloch 2009). In this way, partnership can support the development of the active and engaged "student as producer" (Neary 2014) or "student as scholar" (Hodge et al. 2011; Curley and Schloenhardt 2014) identities often championed by advocates of research-based education. Indeed, as noted by Brew $(2006,32)$, the notion of student-staff partnership is central to the "inclusive scholarly knowledge-building communities" fundamental to bridging the teaching-research divide.

\section{The McMaster Context}

McMaster University is a mid-size, medical-doctoral institution in Hamilton, Ontario. It currently enrolls approximately 22,000 undergraduates and 3,500 graduate students in programs that sit within and/or draw from six major faculties (business, engineering, health sciences, humanities, science, and social sciences). As a research-intensive institution that simultaneously seeks to prioritize the student experience, the university has a relatively long history of fostering and supporting research-based learning, including a well-established award program for undergraduate student research (Vajoczki 2010), and the deployment of inquiry approaches in several-although by no means all-courses and programs (Cuneo et al. 2012; Justice et al. 2009). In a recent strategic visioning process, the university reaffirmed its commitment to such approaches, defining itself as a "research focused student centred" institution and thereby positioning the fusion of research and teaching as central to McMaster's institutional identity (Forward with Integrity Advisory Group 2012).

The MacPherson Institute - the university's central teaching and learning unit-aims to contribute to the realization of this vision in several ways. Continuing the former teaching and learning center's support for inquiry-based learning (Cuneo et al. 2012), a campus-wide research working group on undergraduate research and inquiry was recently established, and this topic was positioned as a priority area for research conducted and supported by the institute. Mick Healey was also appointed as a distinguished scholar affiliated with the unit in 2015, with the mandate of supporting initiatives connected to research-based learning and student partnerships and mentoring junior scholars in these areas. Finally, a novel student partners program was designed to provide students with opportunities to partner with faculty and staff on teaching and learning research (and other pedagogical initiatives) outside the formal curriculum. This article focuses on the latter initiative.

\section{The Student Partners Program}

The Student Partners Program (SPP) was developed collaboratively by the MacPherson Institute and the undergraduate Arts \& Science program - a program that itself has a long history of interdisciplinary, inquiry-based learning (Jenkins, Ferrier, and Ross 2004). At its core, the SPP aims to foster the development of meaningful student-faculty/staff partnerships that contribute to the enhancement of teaching and learning at McMaster while providing opportunities for personal and professional development for all individuals involved. Three times a year, MacPherson staff (often working collaboratively with faculty, staff, and/or students from other departments on campus) are invited to submit projects to be considered for inclusion in the SPP. The projects must focus on teaching and learning in some way and typically involve co-design of courses or curricula, or (most commonly) coinquiry on scholarship of teaching and learning projects. Research projects included in the program to date have drawn from a wide range of disciplinary paradigms and methodological approaches. In 2015-2016, for example, program research ranged from a mixed-methods study of the impact of collaborative testing on student performance in undergraduate physics courses and a qualitative investigation of instructors' experiences of pedagogical innovation to a project involving critical close reading of the representations of higher education in popular film. 
A committee consisting of students and staff reviews all project proposals to ensure they align with program goals and provide meaningful opportunities for collaboration and student contributions to the intellectual direction of the work. Accepted projects are then circulated in a call for applications, and students are invited to select work of interest to them and write an application statement that explains their attraction to the project and goals for its development. In this way, they are encouraged to articulate directions and raise ideas that might shape future stages of the project at the outset of the application process.

Ultimately, selected students are hired to work at MacPherson (in paid positions) for up to 10 hours a week during one or more academic terms, becoming full members of institute project teams. Throughout this time, they work collaboratively with their faculty/staff partners to determine the specific nature of their contributions and the ways in which the team will work together. Regardless of the type of project involved, the aim is to develop working relationships that align with the definition of partnership by Cook-Sather and colleagues (2014); students and staff should have opportunities to contribute substantively and to develop a sense of shared ownership for the work. Students working on SoTL research, for example, often become heavily involved in project design, data collection and analysis, and/or dissemination of findings, with several coauthoring conference presentations or publications connected to their work. Partners are encouraged to meet frequently (particularly early in the project) to get to know one another and establish trust; and to have frank conversations up front about expectations, timelines, and individual and collective goals.

In winter 2014, the program was piloted with 13 undergraduate students representing years 1 to 4 of the Arts $\&$ Science program. Subsequently, responding to calls to make partnership opportunities as broadly available as possible (e.g., Felten et al. 2013), the program was expanded to include undergraduate and graduate students from across campus. Currently, approximately 50 students work as student partners during each academic term. Since the program's inception, more than 115 students have participated, many for multiple work terms. The vast majority of these students (more than 80 percent) are undergraduates who are mainly in their second, third, or fourth years of study. Thus far, most (more than 70 percent) have been women. Students from all faculties on campus have taken part, with the largest concentrations coming from the Faculty of Science and the Arts \& Science program.

\section{Assessment of the Program}

Like work focusing on undergraduate research and inquiry, existing scholarship suggests the benefits of partnership approaches are manifold. Most germane to the present exploration, some research illustrates that students involved in partnership work develop an increasing sense of responsibility for their education and come to view themselves as active collaborators and co-producers within an academic environment (e.g., Cook-Sather and Luz 2015). This work resonates with scholarship on the potential of "students as producers" initiatives to counter discourses of academic capitalism (Neary 2014) and with literature on the ability of inquiry-based learning to increase students' self-direction and sense of responsibility for their learning (Hodge et al. 2011).

At the same time, some authors have noted that the benefits of student-faculty partnership have often been assumed and promoted uncritically, whereas - in factpositive partnership outcomes are neither assured nor always easy to promote (Allin 2014). Navigating existing hierarchies and institutional structures to develop meaningful partnerships is often especially challenging, and both students and faculty may express resistance or experience uncertainty about how to proceed (Bovill et al. 2016). The time required to build effective partnerships exacerbates these challenges, particularly since students are often involved in projects for comparatively short periods (Levy, Little, and Whelan 2011). Finally, Felten and colleagues (2013) and Bovill and colleagues (2016) note the need to consider carefully the relative inclusivity of student-faculty partnerships, pointing out that partnership opportunities are sometimes restricted to a small group of relatively privileged students and that the benefits of such approaches are thus diminished or restricted.

Such considerations provide the basis for the ongoing assessment of the student partners program and the extent to which it is able to meet its goals of developing meaningful partnerships and providing opportunities for personal and professional growth. On a surface level, the involvement of students in more than 70 projects through the Student Partners Program has provided those students with valuable opportunities to engage in research (and other teaching and learning initiatives) that draw from a range of epistemological and methodological approaches. Likewise, at least 45 of these students have coauthored publications and conference presentations with faculty and staff partners to date, with further submissions in development on a continuous basis. These are promising signs. Nevertheless, they reveal a limited amount about the effectiveness and benefits of the partnerships for the participants.

With this in mind, a group of students and staff collaborated during the program's pilot year to develop an exploratory research project investigating participant experiences (Marquis et al. 2016). Acknowledging the simultaneously troublesome and potentially transformative character of partnership work, this research followed Cook-Sather (2014) in positioning student-faculty/staff partnership as a threshold concept for teaching and learning - a centrally 
important concept that is difficult to master but ultimately leads to substantial and durable shifts in understanding (Meyer and Land 2006). Although this threshold might look slightly different for students and faculty/staff, it was argued that two essential features for both groups would be involved:

- understanding teaching and learning as a collaborative endeavor for which faculty, staff, and students have shared responsibility and

- acting effectively on that understanding so as to realize partnership in practice.

The research team (four students and four staff) took an auto-ethnographic approach to assess the extent to which they crossed this threshold successfully during the first year of the Student Partners Program. A series of reflective prompts were co-developed on topics ranging from understandings of partnership to challenges and successes experienced working on the projects, and participants completed individual reflective responses to these sporadically over a two-month period. Subsequently a focus group involving seven of the eight team members was convened, during which the co-developed prompts were used to guide discussion. The qualitative data were then analyzed thematically, using constant comparison.

Significantly, many (but not all) participating students offered comments that were indicative of developing a new sense of themselves as active, collegial contributors to teaching and learning, although some suggested that this was not always a smooth or comfortable transition. Likewise, the data provided several examples of participants successfully realizing partnership goals in their work, as both students and faculty described moments of experiencing a sense of shared responsibility for their projects and offered examples of how the diversity of perspectives involved ultimately enhanced the work being undertaken. Nevertheless, participants also noted a range of challenges they experienced in working toward those goals, citing discomforts and difficulties navigating traditional roles and expectations as well as time pressures that often tested the development of working relationships and prevented the partnerships from reaching full strength. (See Table 1 for a summary of the findings, and Marquis et al. 2016 for further details).

This range of findings suggested that the Student Partners Program can build participants' capacity to work in partnership but that strategies were needed to address the difficulties encountered by students and faculty/staff. A group of staff and students subsequently developed a guidebook for participants in the program, which presented a range of recommendations based on the authors' experiences and readings of the literature-including the previously mentioned points about frequent meetings and candid discussions of expectations. Follow-up case
TABLE 1. Summary of Key Themes Resulting from Pilot Research

\begin{tabular}{|l|l|}
\hline $\begin{array}{l}\text { Issues connected to enacting } \\
\text { partnership }\end{array}$ & $\begin{array}{l}\text { Shifts in understanding for } \\
\text { those involved }\end{array}$ \\
\hline $\begin{array}{l}\text { Challenges navigating } \\
\text { traditional roles }\end{array}$ & $\begin{array}{l}\text { New perspectives on } \\
\text { one's role }\end{array}$ \\
\hline $\begin{array}{l}\text { Difficulty balancing guidance } \\
\text { and self-direction }\end{array}$ & $\begin{array}{l}\text { New perspectives on teaching } \\
\text { and learning }\end{array}$ \\
\hline Time pressures and constraints & \\
\hline $\begin{array}{l}\text { Students playing meaningful } \\
\text { roles }\end{array}$ & \\
\hline Enhanced work & \\
\hline
\end{tabular}

Source: Marquis et al. 2016

studies developed by students and staff participating in subsequent iterations of the program (Marquis et al. forthcoming) suggest these increasing refinements (along with the growing experience of staff and students) have proven beneficial, although further research exploring these developments is merited.

One additional issue that bears consideration is the question of inclusion and diversity raised by Felten and colleagues (2013) and Bovill and colleagues (2016). As a paid opportunity outside the curriculum, the Student Partners Program will always have the problem of needing to select participants and thus can never be fully inclusive. In this way, it shares features of extracurricular undergraduate research opportunities that are only available to a select group (Healey and Jenkins 2009). Nevertheless, the comparatively large number of students accepted by the program each year mitigates this issue to some degree, providing an expanding body of students with a more thorough partnership experience than they might otherwise encounter within a course or program. Furthermore, drawing from recommendations made by Bovill and colleagues (2016), the call for student participants is being refined with an eye toward including participants with a wide range of experiences and perspectives, such as members of equity-seeking groups and those traditionally marginalized in higher education. Although such efforts are only a first step in a larger process, they should assist in enhancing the inclusivity of the program.

\section{Implications and Conclusions}

Considerations of research-based learning often emphasize how such pedagogical approaches can help students develop as active scholars and knowledge producers, rather than positioning them as passive recipients of information. Strategies and initiatives that emphasize the development of student-faculty partnerships, exemplified here by McMaster's Student Partners Program, can likewise contribute to such desirable outcomes - perhaps even 
more so by virtue of their explicit emphasis on partnership and collaboration. Although the McMaster program is certainly not the only model for developing partnership, the experiences at this institution highlight a number of factors that might be of interest to others considering such work, including the benefits and challenges of a paid, extracurricular program supported by a central unit, the value of engaging in reflection and research as the program develops, and the significance of collaboratively developing and documenting refinements in materials like the coauthored guidebook previously mentioned (available at https:// mi.mcmaster.ca/student-partners-program/). Perhaps most important, ongoing evaluation suggests an approach like the Student Partners Program can develop student and staff capacity to work in meaningful, collaborative relationships that encourage a sense of shared responsibility, ownership, and intellectual contribution. Likewise, the challenges experienced by partners in moving toward these outcomes illuminate the potential difficulties in meaningfully destabilizing the "student as consumer" model.

With these factors in mind, more explicit consideration of the potential place of partnership within undergraduate research and inquiry might prove valuable for researchers interested in advancing the notion of "students as scholars." Existing hierarchies and role expectations, so commonly discussed in the partnership literature, could be considered more thoroughly in undergraduate research and inquiry, as could the experiences of and benefits for faculty engaged in such work.

\section{References}

Allin, Linda. 2014. "Collaboration between Staff and Students in the Scholarship of Teaching and Learning: The Potential and the Problems." Teaching \& Learning Inquiry 2(1): 95-102. doi: 10.2979/teachlearninqu.2.1.95

Bovill, Catherine, Alison Cook-Sather, Peter Felten, Luke Millard, and Niamh Moore-Cherry. 2016. "Addressing Potential Challenges in Co-creating Learning and Teaching: Overcoming Resistance, Navigating Institutional Norms and Ensuring Inclusivity in Student-Staff Partnerships." Higher Education 71: 195-208. doi: 10.1007/s10734-015-9896-4

Brew, Angela. 2006. Research and Teaching: Beyond the Divide. Houndsmills, UK: Palgrave.

Cook-Sather, Alison. 2014. "Student-Faculty Partnership in Explorations of Pedagogical Practice: A Threshold Concept in Academic Development." International Journal for Academic Development 19: 186-198. doi: 10.1080/1360144x.2013.805694

Cook-Sather, Alison, and Alia Luz. 2015. "Greater Engagement in and Responsibility for Learning: What Happens When Students Cross the Threshold of Student-Faculty Partnership." Higher Education Research \& Development 34: 1097-1109. doi: 10.1080/07294360.2014.911263

Cook-Sather, Alison, Catherine Bovill, and Peter Felten. 2014. Engaging Students as Partners in Learning and Teaching: A Guide for Faculty. San Francisco: Jossey-Bass.
Cuneo, Carl, Del Harnish, Dale Roy, and Susan Vajoczki. 2012. "Lessons Learned: The McMaster Inquiry Story from Innovation to Institutionalization." New Directions for Teaching and Learning 129: 93-104. doi: 10.1002/tl.20010

Curley, Melissa, and Andreas Schloenhardt. 2014. "Undergraduate Research and Human Rights: An Australian Case Study on Human Trafficking and Migrant Smuggling." CUR Quarterly 34(3): 24-29.

Felten, Peter, Julianne Bagg, Michael Bumbry, Jennifer Hill, Karen Hornsby, Maria Pratt, and Saranne Weller. 2013. "A Call for Expanding Inclusive Student Engagement in SoTL." Teaching and Learning Inquiry 1(2): 63-74. doi: 10.20343/teachlearninqu.1.2.63

Forward with Integrity Advisory Group. 2012. "Forward with Integrity: The Emerging Landscape." Accessed January 24, 2017. http://president.mcmaster.ca/reports/fwi/

Healey, Mick, Abbi Flint, and Kathy Harrington. 2014. Engagement through Partnership: Students as Partners in Learning and Teaching in Higher Education. York, UK: Higher Education Academy. https://www.heacademy.ac.uk/engagement-throughpartnership-students-partners-learning-and-teaching-higher-education. doi: 10.1080/1360144x.2016.1124966

Healey, Mick, and Alan Jenkins. 2009. Developing Undergraduate Research and Inquiry. York, UK: Higher Education Academy. https://www.heacademy.ac.uk/resource/developingundergraduate-research-and-inquiry

Hodge, David C., Marjorie Nadler, Cecilia Shore, and Beverley Taylor. 2011. "Institutionalizing Large-Scale Curricular Change: The Top 25 Project at Miami University." Change 43(5): 28-35. doi: 10.1080/00091383.2011.599290

Jenkins, Herb, Barbara Ferrier, and Michael L. Ross (Eds.). 2004. Combining Two Cultures: McMaster University's Arts and Science Program. Lanham, MD: University Press of America.

Justice, Christopher, James Rice, Dale Roy, Bob Hudspith, and Herb Jenkins. 2009. "Inquiry-Based Learning in Higher Education: Administrators' Perspectives on Integrating Inquiry Pedagogy into the Curriculum." Higher Education 58: 841-855. doi: 10.1007/s10734-009-9228-7

Levy, Philippa. 2011. "Embedding Inquiry and Research into Mainstream Higher Education: A UK Perspective." CUR Quarterly 32(1): 36-42.

Levy, Philippa, Sabine Little, and Natalie Whelan. 2011. "Perspectives on Staff-Student Partnership in Learning, Research and Educational Enhancement." In Staff-Student Partnerships in Higher Education, ed. Sabine Little, 1-15. New York: Continuum.

Little, Sabine (Ed). 2011. Staff-Student Partnerships in Higher Education. New York: Continuum.

Marquis, Elizabeth, Varun Puri, Stephanie Wan, Arshad Ahmad, Lori Goff, Kris Knorr, Ianitza Vassileva, and Jason Woo. 2016. "Navigating the Threshold of Student-Staff Partnerships: A Case Study from an Ontario Teaching and Learning Institute." International Journal for Academic Development 21(4): 4-15. doi: 10.1080/1360144x.2015.1113538

Marquis, Elizabeth, Zeeshan Haqqee, Sabrina Kirby, Alexandra Liu, Robert Cockcroft, Lori Goff, and Kris Knorr. Forthcoming. 
"Connecting Students and Staff for Teaching and Learning Inquiry: The McMaster Student Partners Program." In Disciplinary Approaches to Connecting the Higher Education Curriculum, ed. Brent Carnell and Dilly Fung. London: UCL Press.

McCulloch, Alistair. 2009. "The Student as Co-Producer: Learning from Public Administration about the Student-University Relationship." Studies in Higher Education 34: 171-183. doi: 10.1080/03075070802562857

Meyer, Jan H. F., and Ray Land (Eds.). 2006. Overcoming Barriers to Student Understanding: Threshold Concepts and Troublesome Knowledge. London: Routledge.

Neary, Mike. 2014. "Student as Producer: Research-Engaged Teaching Frames University-Wide Curriculum Development." CUR Quarterly 35(2): 28-34.

Shanahan, Jenny Olin, Elizabeth Ackley-Holbrook, Eric Hall, Kearsley Stewart, and Helen Walkington. 2015. "Ten Salient Practices of Undergraduate Research Mentors: A Review of the Literature." Mentoring \& Tutoring: Partnership in Learning 23: 359-376. doi: 10.1080/13611267.2015.1126162

Vajoczki, Susan. 2010. "A Canadian Perspective on Undergraduate Research.” CUR Quarterly 31(2): 41-47.
Werder, Carmen, and Megan M. Otis (Eds.). 2010. Engaging Student Voices in the Study of Teaching and Learning. Sterling, VA: Stylus.

\section{Elizabeth Marquis}

McMaster University, beth.marquis@mcmaster.ca

Beth Marquis is an assistant professor in the Arts \& Science Program at McMaster University and associate director (research) at the Paul R. MacPherson Institute for Innovation, Leadership, and Excellence in Teaching. She serves as senior editor of the Canadian Journal for the Scholarship of Teaching and Learning, and is co-presidentelect of the International Society for the Scholarship of Teaching \& Learning (ISSOTL). Marquis's SoTL research focuses on the intersections between teaching and learning and questions of equity and justice, and on film and media texts as public pedagogy. She is also committed to supporting and researching student-staff partnerships in higher education and oversees McMaster's Student Partners Program. 